\title{
The Role of Tree Mortality in Vitality Assessment of Sessile Oak Forests
}

\author{
Imre Berki ${ }^{1}$, Ervin Rasztovits ${ }^{2}$, Norbert Móricz² ${ }^{2}$ László Kolozs $^{3}$
}

(1) University of West Hungary, Institute of Environmental and Earth Sciences, Bajcsy-Zsilinszky 4., H-9400 Sopron, Hungary; (2) National Agricultural Research and Innovation Centre, Forest Research Institute, Várkerület 30/A, H-9600 Sárvár, Hungary; (3) National Food Chain Safety Office, Keleti Károly 24., H-1024 Budapest, Hungary

* Correspondence: e-mail: rasztovitse@erti.hu
Citation: BERKII, RASZTOVITS E, MÓRICZ N, KOLOZS L 2016 The Role of Tree Mortality in Vitality Assessment of Sessile Oak Forests. South-east Eur for 7 (2): 91-97. DOI: https:// doi.org/10.15177/seefor.16-14

Received: 13 Jun 2016; Revised: 1 Sep 2016; 9 Nov 2016; Accepted: 10 Nov 2016; Published online: 28 Nov 2016

\begin{abstract}
Background and Purpose: The drought-induced vitality loss of sessile oak (Quercus petraea (Matt.) Liebl.) has been continuously observed in Hungary for more than three decades. The decrease in stand density as a consequence of drought-induced mortality has not been taken into consideration in most of the monitoring methods.

Materials and Methods: Forest stands without any forest intervention during the last 30 years were selected. Quadrats were designated for the analysis in 18 sessile oak stands along a climatic transect in which foliage transparency and stand density were measured. Drought stress was defined by the water balance approach. By combining the foliage transparency and the relative stand density, a new cumulative assessment method of stand level vitality was introduced to get a more realistic picture about the effects of long-term drought (lasting for several decades) on the sessile oak forests in South-East Europe.

Results: The calculated health status (100\% - vital; $0 \%$ - dead) of the sessile oak stands was between $70-90 \%$ in the moist South-West Hungary and below $50 \%$ close to its xeric limit. The individual tree-based vitality assessment method gave considerably higher values on 17 out of 18 sites.

Conclusions: Forest monitoring should also consider stand level-based tree mortality in oak forests while assessing health condition especially close to its xeric limit. The proposed new method provides a more realistic picture about the effects of climate change on sessile oak stands particularly for forest managers interested in changing in the wood stock of forests.
\end{abstract}

Keywords: Quercus petraea (Matt.) Liebl., drought, mortality, stand density, forest monitoring

\section{INTRODUCTION}

Global climate change, in particular warming, has been observed in all parts of the world [1], including Europe, where several severe drought periods have occurred during the last decades [2]. The climate of the Carpathian basin has also become more arid during the last 50 years. The mean annual temperature has increased while precipitation during vegetation season has decreased $[3,4]$. In the future, the frequency and probability of drought periods may increase, resulting in higher evapotranspiration [5-8] and prolonged water stress.

Since the mid 1970s, droughts tended to occur in subsequent years in Hungary, which led to prolonged water deficits, partly owing to higher evapotranspiration caused by higher temperatures during the growing season [9]. Since water is one of the limiting resources for trees on the xeric limit, and since it is also needed for transporting nutrients, drought could decrease the vitality of trees [10], reduce tree growth [11, 12], alter their crown leaf structures with increased percentages of defoliation, [13] and ultimately lead to tree death [14], consequently reducing stand density [15].

Sessile oak (Quercus petraea (Matt.) Liebl.) forests are one of the most important forest communities in the Carpathian basin, covering $20.8 \%$ of the total forested area in Hungary. Since the early 1980s, the severe dry periods have triggered mass mortality of stand-forming forest tree species including Quercus petraea [16, 17]. The multiyear drought in the beginning of the 1990s was especially severe 
and affected oak forests mainly in the northeastern part of Hungary. These episodic diebacks acted as a self-thinning mechanism to adapt tree density to decreased soil water resources during acute summer droughts.

Different approaches (e.g. ecophysiological, dendroecological, growth modelling) used for the evaluation of stand density change might give different insights [18, 19], but reduced stand density increases water resources, nutrient and light for the retained trees by decreasing competition and canopy interception [20]. Therefore, stand opening could facilitate the regeneration of the surviving trees after drought periods [20, 21]. Improved water availability may reduce the risks of cavitation for trees and thus have a positive effect on stomata opening and consequently also on carbon uptake and growth. The results by McMahon et al. [22] indicated an increase for living above-ground forest biomass in the Mid-Atlantic region of the United States, but failed to account past mortality rates that could explain the deviation from the expected rate of biomass change [23]. Improving carbon uptake should mitigate further mortality by allowing the remaining trees to produce enough carbohydrates for their metabolism and defense against biotic attacks [24]. Gracia et al. [25] showed that thinning treatments of Quercus ilex L. facilitated to overcome severe drought episodes. Nevertheless, stand opening does not ultimately improve water availability since increasing light intensity may lead to a higher temperature at the ground level, which results in higher soil water evaporation and the development of a dense understorey vegetation. A recent study by Misik et al. [26] showed that Acer campestre L. responded successfully to the foliage gaps of sessile oak trees by forming a subcanopy layer. However, the subsequent establishment of grasses after self-thinning could prevent retained trees from benefiting from increased available soil water [27].

The Europe-wide existing forest monitoring system of ICP (International Cooperative Programme on Assessment and Monitoring of Air Pollution Effects on Forests - Level
I) offers a suitable, continent-wide evaluation of the forest vitality [28]. ICP was designed to detect and monitor changes of the health condition of living tree individuals annually. Thus, stand level data on Level I plots is not taken into account, although it might be an important indicator of the stand productivity for forest managers. In case of scattered and fragmented forest covers, a considerable number of grid intersections may fall outside of the forests, especially in semiarid regions at the retreating edge of the species distribution [29].

We aimed (1) to extend the established and widely used individual tree-based vitality assessment method with a stand level-based approach for oak forests near the xeric limit which incorporates the effects of the former mortality events through stand density. We have compared the results (2) of the different approaches along a climatic transect in Hungary.

\section{MATERIALS AND METHODS}

\section{Investigated Stands}

Forest stands without any forest intervention during the last 30 years were selected since a middle-aged sessile oak stand under average weather conditions in Hungary could outgrow an intermediate thinning (30\%) within three decades [30]. Stands with wind/snow throw, nitrogen deficiency or pest outbreaks were excluded, resulting that the observed tree mortality was triggered exclusively by drought-induced mortality.

A 50x50 m quadrat was designated for the analysis in 18 sessile oak stands along the climatic transect from the humid region in South-West Hungary to the continentalsemiarid region in North-East Hungary in 2011 (Figure 1).

The 60-100 years old sessile oak stands are situated in zonal position without major confounding factors among the stands (e.g. exposition, steep slope, seeping water). The mean annual precipitation sum ranges from $550 \mathrm{~mm}$ to 730

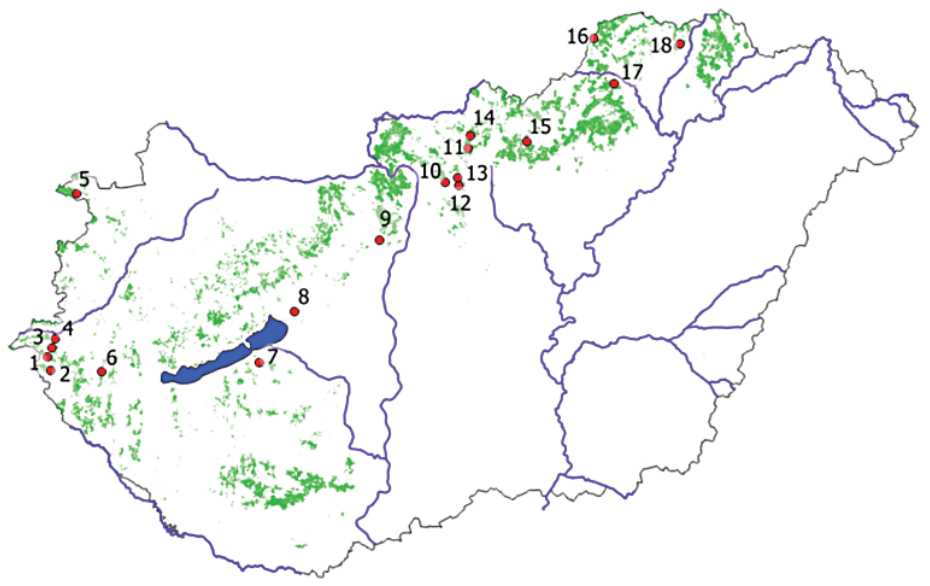

FIGURE 1. The investigated sessile oak stands in Hungary 
$\mathrm{mm}$. The mean annual air temperature changes between $8.5^{\circ} \mathrm{C}$ and $10.8^{\circ} \mathrm{C}$ [31]. The soil texture of the stands is loam and the soil can be characterized by deep fertile upper layer $(>10 \mathrm{~cm})$ in all sites (Table 1$)$.

Foliage transparency is defined as the additional amount of skylight visible through the crown compared to the amount of skylight visible through a fully foliated crown. Foliage transparency was estimated in $5 \%$ classes by always the same observer based on the live, normally foliated portion of the crown and branches, excluding branches and large spaces between them [28].

\section{The Definition of the Climatic Water Stress}

The water balance model of Thornthwaite and Mather [32] was applied to quantify the climatic water stress for the stands between 1961 and 2010. Monthly weather data were provided by the CARPATCLIM Database [31] and interpolated climate data outside of CARPATCLIM target area provided by the Hungarian Meteorological Service (OMSz) were used. The maximum extractable soil water $\left(E W_{m}\right)$ was derived from soil texture and rooting depth using soil pit data of the assessed quadrats.

The water stress index $\left(I_{s}\right)$ was calculated according to the methodology of Granier et al. [33]. Water stress was assumed to occur when the relative extractable water $\left(\right.$ REW $\left.=E W / E_{m}\right)$ drops below $0.4\left(\right.$ REW $\left._{c}\right)$ under which transpiration is gradually reduced due to stomatal closure. Soil water deficit (SWD) was calculated as follows:

$$
\mathrm{SWD}=\mathrm{EW}_{\mathrm{m}} \times 0.4-\mathrm{EW}
$$

Water stress index cumulates the difference between REW and REW for the vegetation period (April-September):

$$
\mathrm{I}_{\mathrm{S}}=\sum \mathrm{SWD} / \mathrm{EW}_{\mathrm{m}}
$$

\section{Novel Method for the Assessment of the Health Condition}

The thinning of the crown and top drying are among the typical consequences of prolonged droughts. Eventually, a major part of the affected trees recover from the decline, but some trees die due to the severe conditions which reduce stand density.

We proposed a new method for the assessment of stand vitality which considered not only the health condition of living trees, but also the effect of mortality on the stand density. The health condition of the forest stand $\left(\mathrm{H}_{\text {sta } \%}\right)$ is defined by two indicators:

\begin{tabular}{|c|c|c|c|c|c|c|c|c|}
\hline $\begin{array}{l}\text { Stand } \\
\text { No. }\end{array}$ & $\begin{array}{c}\text { Annual mean air } \\
\text { temperature } \\
1975-2010 \\
\left({ }^{\circ} \mathrm{C}\right)\end{array}$ & $\begin{array}{c}\text { Mean annual } \\
\text { precipitation sum } \\
1975-2010 \\
(\mathrm{~mm})\end{array}$ & $\begin{array}{l}\text { Soil } \\
\text { texture }\end{array}$ & $\begin{array}{l}\text { Stand } \\
\text { age }\end{array}$ & $\begin{array}{c}\text { Mixing ratio } \\
\text { of sessile oak } \\
(\%)\end{array}$ & $\begin{array}{l}\text { Mean } \\
\text { height } \\
(\mathrm{m})\end{array}$ & $\begin{array}{l}\text { Mean } \\
\text { diameter } \\
(\mathrm{cm})\end{array}$ & $\begin{array}{l}\text { Stand density } \\
\left(\text { trees }^{\prime} \mathrm{ha}^{-1}\right)\end{array}$ \\
\hline 1 & 10.0 & 725 & $\begin{array}{l}\text { clay } \\
\text { loam }\end{array}$ & 76 & 95 & 25.9 & 39.2 & 253 \\
\hline 2 & 10.0 & 717 & $\begin{array}{l}\text { clay } \\
\text { loam }\end{array}$ & 70 & 98 & 26.3 & 38.1 & 290 \\
\hline 3 & 10.0 & 715 & $\begin{array}{l}\text { clay } \\
\text { loam }\end{array}$ & 93 & 96 & 27.3 & 34.0 & 374 \\
\hline 4 & 10.0 & 708 & $\begin{array}{l}\text { clay } \\
\text { loam }\end{array}$ & 78 & 90 & 28.0 & 41.1 & 259 \\
\hline 5 & 10.2 & 675 & loam & 86 & 98 & 22.6 & 32.6 & 335 \\
\hline 6 & 9.9 & 692 & $\begin{array}{l}\text { clay } \\
\text { loam }\end{array}$ & 76 & 95 & 29.9 & 32.8 & 433 \\
\hline 7 & 10.4 & 630 & loam & 77 & 99 & 22.4 & 30.4 & 340 \\
\hline 8 & 10.8 & 575 & loam & 69 & 91 & 16.4 & 23.9 & 420 \\
\hline 9 & 9.6 & 549 & loam & 91 & 97 & 21.0 & 35.7 & 267 \\
\hline 10 & 9.9 & 558 & loam & 65 & 95 & 17.3 & 23.8 & 400 \\
\hline 11 & 9.3 & 567 & $\begin{array}{l}\text { clay } \\
\text { loam }\end{array}$ & 69 & 98 & 22.2 & 26.9 & 370 \\
\hline 12 & 9.8 & 548 & loam & 100 & 89 & 21.1 & 30.5 & 330 \\
\hline 13 & 9.5 & 550 & loam & 61 & 88 & 18.6 & 22.6 & 496 \\
\hline 14 & 9.1 & 569 & $\begin{array}{l}\text { clay } \\
\text { loam }\end{array}$ & 77 & 89 & 23.6 & 29.4 & 387 \\
\hline 15 & 8.6 & 727 & loam & 75 & 99 & 21.6 & 32.3 & 389 \\
\hline 16 & 9.1 & 661 & $\begin{array}{l}\text { sandy } \\
\text { loam }\end{array}$ & 84 & 93 & 23.0 & 28.6 & 420 \\
\hline 18 & 9.7 & 588 & loam & 86 & 99 & 22.3 & 28.3 & 417 \\
\hline
\end{tabular}

TABLE 1. Main variables of the assessed quadrats 
1) Foliage transparency $\left(\mathrm{H}_{\text {fol } \%}\right)$ of the selected living tree individuals

2) Relative stand density $\left(D_{\text {rel }} \%\right.$, expressed as the ratio of the current density $\left(D_{c u}\right)$ and the fully stocked density $\left(D_{f u}\right)$ of the stand:

$$
D_{\text {rel\% }}=\left(D_{c u} / D_{f u}\right) \times 100
$$

The fully stocked density of a stand is regulated by selfthinning $[34,35]$. We have applied the yield tables of sessile oak in Hungary using the average yield class (III.) to determine the fully stocked density corresponding to the mean stem diameter of the stand. The yield tables were defined in the 1960s when there have not been any significant dry periods causing mass oak mortality yet, and therefore we considered these tables describing healthy stands.

These two indicators can be easily combined, i.e. the health status indicated by the foliage transparency is modified by the relative stand density:

$$
\mathrm{H}_{\text {sta\% }}=\left(\mathrm{D}_{\mathrm{rel} \%} \times\left(100-\mathrm{H}_{\mathrm{fol} \%}\right)\right) / 100
$$

\section{RESULTS AND DISCUSSION}

\section{Relative Stand Density and Foliage Transparency}

The relative stand density ranged from $57 \%$ to $101 \%$ in 2011 in the studied quadrats. As an example, there was a major difference in the relative stand density between two stands (Bak-No.6 and Galgamácsa-No.12) with similar average stem diameters $(33 \mathrm{~cm}$ and $30 \mathrm{~cm}$ respectively) (Figure 2).

The sessile oak stand No. 6 (age: 76 years) is located in the humid south-west part of the country while No. 12 (age: 100 years) is located near the xeric limit of the sessile oak distribution. The prolonged droughts in the past have reduced the relative stand density to $65 \%$ in No. 12 , while in No. 6 the stand density was significantly larger with $101 \%$.

Field observations showed that the mean foliage transparencies were low (below 27\%) in all studied stands with varying relative stand density.

The Relationship between the Health Status of the Stands and the Water Stress Index

The stand level-based method showed that the vitality status $\left(\mathrm{H}_{\text {sta\% }}\right)$ of the sessile oak stands was between $70 \%$ and $90 \%$ in the humid southwestern region of Hungary while it was below 50\% near its xeric limit in 2011 (Figure 3).

Prolonged droughts triggered a significant decrease of the relative stand density in the semiarid regions, while foliage transparency of the survived trees did not change significantly.

The determination of the relative stand density by using yield tables constituted one of the main uncertainties of the study. We assumed that the yield tables defined 50 years ago showed the stand densities for completely healthy stands. Earlier research on oak in Hungary showed that the oak decline began only in the second half of the 1970s, and therefore this assumption could be justified [36, 37]. Moreover, the applied yield tables were defined for the whole country based on scattered measurements and not for specific forest locations. For this reason, we included only the plots with average yield class in the analysis and used the corresponding values in the yield tables.

The long-term climatic water stress was defined using a simple water balance model [32] which originally was not intended to simulate water balance changes in the forested area. Unfortunately, water balance simulations could not be validated against measured soil water content, although the main aim was only to compare the climate conditions of the sites to each other. The application of a daily water balance model was omitted due to the need of a large number of (a)

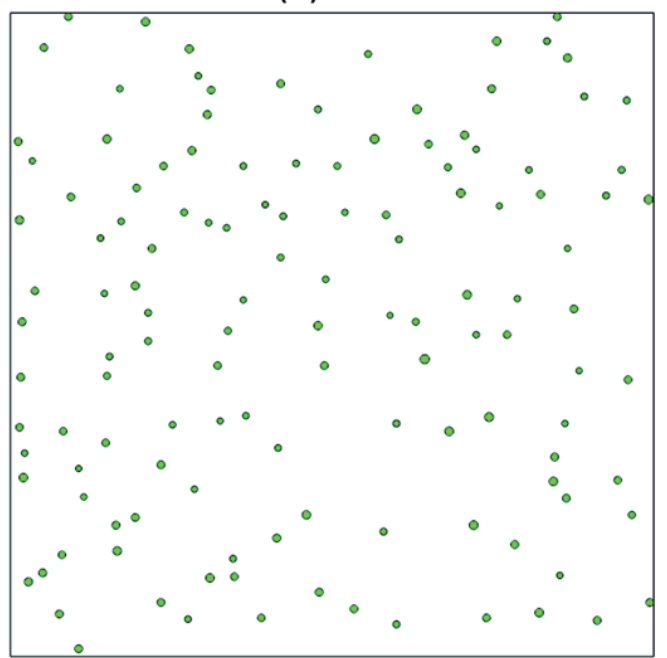

(b)

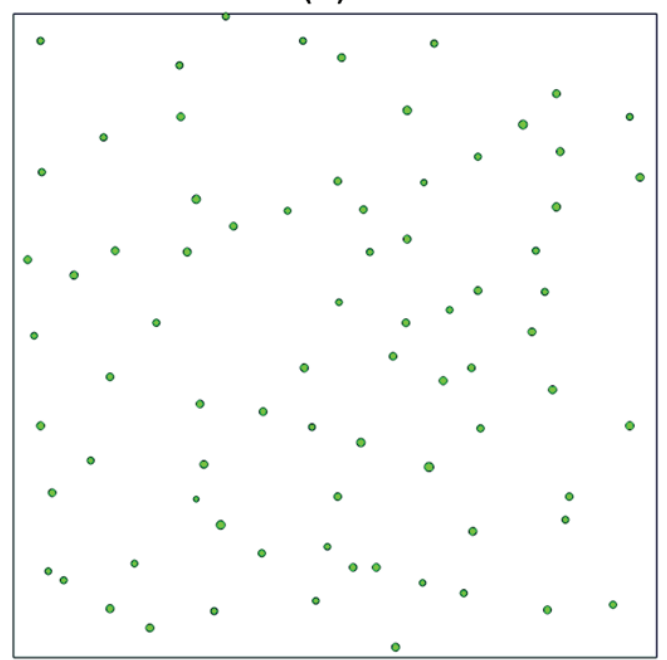

FIGURE 2. The spatial distribution of sessile oak trees in quadrats No. 6 (a) and No. 12 (b) 


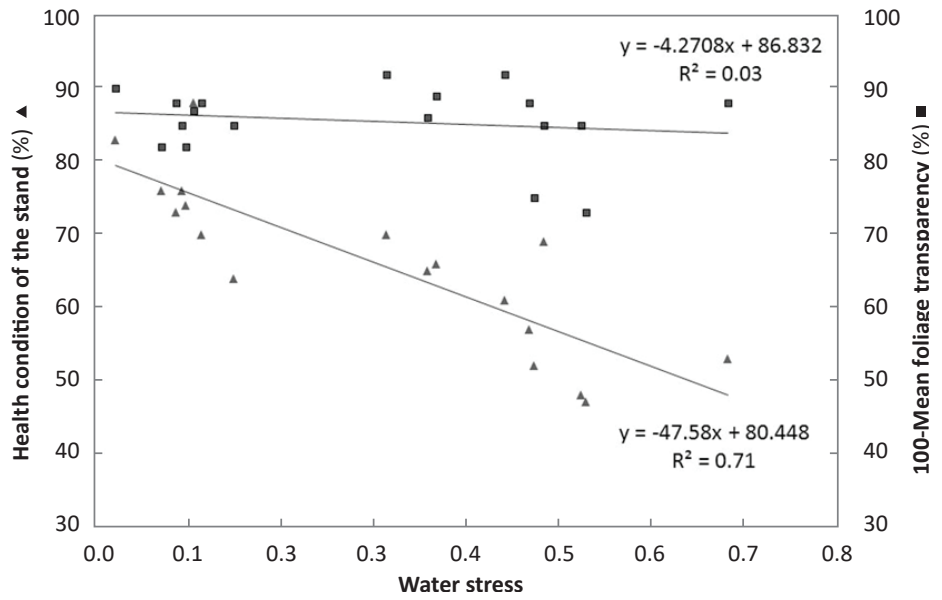

FIGURE 3. The relationship between water stress index (Is) and the health condition $\left(\mathrm{H}_{\text {sta\%}}\right)$ of sessile oak stands (\%) with triangles and the mean foliage transparency $\left(\mathrm{H}_{\text {fol\% }}\right)$ of sessile oak stands $(\%)$ with squares

variables and data to run the model.

The probable cause of the favourable condition of trees in the thinned stands was that transpiration and rainfall interception of the stand have reduced significantly due to the mortality of trees, thus leaving more available water in the soil for the recovery of the survived trees [38]. This way not only the available water in the soil has increased, but also the availability for nutrients.

The potential use of the stand level-based vitality assessment in forest monitoring is limited due to the fact that forest stands without any forest intervention for at least three decades are needed. However, since our results include long-term changes due to drought events, we propose our stand level-based method as complementary to the ICP monitoring. The new method could be implemented on ICP plots situated in national parks, forest gene conservation areas and long-term experiment sites, especially along the xeric limits of tree species.

\section{CONCLUSIONS}

We have introduced a new health assessment method for sessile oak which incorporated relative stand density as the indicator of extra tree mortality due to drought events. 18 sessile oak plots were investigated, on which the stand density and the current health status of trees were determined. Additionally, the water stress was calculated for each plot using a robust water balance model.

The results showed that the current health status of the stands was good in terms of foliage transparency regardless of the magnitude of the long-term water stress. However, if the relative stand density was included in the evaluation then the relationship between the water stress index and the health status became strong. The probable reason for the good condition of the surviving trees was greater availability of water and nutrients due to the extra thinning effect of tree mortality.

The results suggest that forest monitoring should also consider stand-level data in oak forests while assessing the health condition. In our view, this new method provides a more realistic picture about the sessile oak stands, particularly for forest managers interested in changes in the wood stock of forests. The better understanding of the mortality dynamics of oak may also help to predict more reliably the possible shift of its distribution area due to future climate change.

\section{Acknowledgments}

This research was funded by FORGER (FORGER - Towards the Sustainable Management of Forest Genetic Resources) and by the AGRARKLÍMA.2 VKSZ_12-1-2013-0034 projects. 


\section{REFERENCES}

1. IPCC 2013 Summary for Policymakers. In: Stocker TF, Qin D, Plattner GK, Tignor M, Allen SK, Boschung J, Nauels A, Xia Y, Bex V and Midgley PM (eds) Climate Change 2013. The Physical Science Basis. Contribution of Working Group I to the Fifth Assessment Report of the Intergovernmental Panel on Climate Change. Cambridge University Press, Cambridge, United Kingdom and New York, NY, USA

2. REBETEZ M, MAYER H, DUPONT O, SCHINDLER D, GARTNER K, KROPP JP, MENZEL A 2006 Heat and drought 2003 in Europe: a climate synthesis. Ann For Sci 63 (6): 569-577. DOI: https://doi.org/10.1051/forest:2006043

3. DOMONKOS P, KYSELÝ J, PIOTROWICZ K, PETROVIC P, LIKSO T 2003 Variability of extreme temperature events in southcentral Europe during the 20th century and its relationship with large-scale circulation. Int J Climatol 23 (9): 987- 1010. DOI: https://doi.org/10.1002/joc.929

4. SZÉP JANKÓ I, MIKA J, DUNKEL Z 2005 Palmer drought severity index as soil moisture indicator: physical interpretation, statistical behaviour and relation to global climate. Phys Chem Earth 30 (1-3): 231-243. DOI: https:// doi.org/10.1016/j.pce.2004.08.039

5. SCHÄR C, VIDALE PL, LUTHI D, FREI C, HABERLI C, LINIGER MA, APPENZELLER C 2004 The role of increasing temperature variability in European summer heatwaves. Nature 427: 332-336. DOI: https://doi.org/10.1038/ nature02300

6. BENISTON $M$, STEPHENSON DB, CHRISTENSEN OB, FERROCAT, FREI C, GOYETTE S, HALSNAES K, HOLT T, JYLHA K, KOFFI B et al. 2007 Future extreme events in European climate: an exploration of regional climate model projections. Clim Chang 81: 71-95. DOI: https://doi. org/10.1007/s10584-006-9226-Z

7. GÁLOS B, LORENZ PH, JACOB D 2007 Will dry events occur more often in Hungary in the future? Environ Res Lett 2 (3): 034006. DOI: https://doi.org/10.1088/17489326/2/3/034006

8. PIECZKA I, PONGRÁCZ R, BARTOLY J 2011 Comparison of simulated trends of regional climate change in the Carpathian basin for the 21st century using three different emission scenarios. Acta Silvatica et Lignaria Hungarica 7: 9-22

9. SZINELL CS, BUSSAY A, SZENTIMREY T 1998 Drought tendencies in Hungary, Int J Climatol 18 (13): 14791491. DOI: https://doi.org/10.1002/(SICI)10970088(19981115)18:13<1479::AID-JOC325>3.0.CO;2-P

10. MARTÍNEZ-VILALTA J, PINOL J 2002 Drough-induced mortality and hydraulic architecture in pine populations of the NE Iberian Peninsula. For Ecol Manage 161 (1-3): $247-$ 256. DOI: https://doi.org/10.1016/S0378-1127(01)00495-9

11. BIGLER C, BRÄKER OU, BUGMANN $H$, DOBBERTIN $M$, RIGLING A 2006 Drought as incinting mortality factor in Scots Pine stands of the Valais, Switzerland. Ecosystems 9 (3): 330-343. DOI: https://doi.org/10.1007/s10021-0050126-2

12. BERTINI G, AMORIELLO T, FABBIO G, PIOVOSI M 2011 Forest growth and climate change: evidences from the ICP-Forests intensive monitoring in Italy. iForest 4: 262-267. DOI: https://doi.org/10.3832/ifor0596-004

13. CARNICER J, COLL M, NINYEROLA M, PONS X, SÁNCHEZG, PEÑUELAS J 2010 Widespread crown condition decline, food web disruption, and amplified tree mortality with increased climate change-type drought. PNAS 108 (4): 1474-1478. DOI: https://doi.org/10.1073/pnas.1010070108
14. REBETEZ M, DOBBERTIN M 2004 Climate change may already threaten Scots pine stands in the Swiss Alps. Theor Appl Climatol 79 (1): 1-9. DOI: https://doi.org/10.1007/ s00704-004-0058-3

15. MARTÍNEZ-VILALTA J, COCHARD H, MENCUCCINI M, STERCK F, HERRERO A, KORHONEN JFJ, LLORENS P, NIKINMAA E, NOLE A, POYATOS R, et al. 2009 Hydraulic adjustments of Scots pine across Europe. New Phytol 184 (2): 353-364. DOI: https://doi.org/10.1111/j.1469-8137.2009.02954.x

16. JAKUCS 1988 Ecological approach to forest decay in Hungary. Ambio 17 (4): 267-274

17. VAJNA L 1990 Fungi associated with oak-decline. EPPO Bulletin 20: 3

18. MISSON L, ANTOINE N, GUIOT J 2003 Effects of thinning intensities on drought response in Norway spruce (Picea abies (L.) Karst.). For Ecol Manage 183 (1-3): 47-60. DOI: https://doi.org/10.1016/S0378-1127(03)00098-7

19. MORENO G, CUBERA E 2008 Impact of stand density on water status and leaf gas exchange in Quercus ilex. For Ecol Manage 254 (1): 74-84. DOI: https://doi.org/10.1016/i. foreco.2007.07.029

20. AUSSENAC G 2000 Interactions between forest stand and microclimate: Ecophysiological aspects and consequences for silviculture. Ann For Sci 57 (3): 287-301. DOI: https://doi. org/10.1051/forest:2000119

21. WARING RH, SCHLESINGER WH 1985 Forest ecosystems: concepts and management. Academic Press Inc., Orlando, FL, USA, $340 p$

22. MCMAHON SM, PARKER GG, MILLER DR 2010 Evidence for a recent increase in forest growth. PNAS 107 (8): 36113615. DOI: https://doi.org/10.1073/pnas.0912376107

23. FOSTER JR, BURTON JI, FORRESTER JA, LIU F, MUSS JD, SABATINI FM, SCHELER RM, MLADENOFF DJ 2010 Evidence for a recent increase in forest growth is questionable. PNAS 107 (21): E86-E87. DOI: https://doi.org/10.1073/ pnas. 1002725107

24. KOLB TE, AGEE JK, FULE PZ, MCDOWELL NG, PEARSON K, SALA S, WARING RH 2007 Perpetuating old ponderosa pine. For Ecol Manage 249 (3): 141-157. DOI: https://doi. org/10.1016/j.foreco.2007.06.002

25. GRACIA CA, TELLO E, SABATE S, BELLOT J 1999 GOTILWA: An integrated model of water dynamics and forest growth. In: Roda F, Retana J, Gracia CA, Bellot J (eds) Ecology of Mediterranean Evergreen Oak Forests. Springer, Berlin, Germany, pp 163-179. DOI: https://doi.org/10.1007/9783-642-58618-7

26. MISIK T, KÁRÁSZ I, TÓTHMÉRÉSZ B 2014 Understory Development in an Oak Forest in Northern -Hungary: the Subcanopy Layer. Acta Silvatica et Lignaria Hungarica 10 (1): 9-21. DOI: https://doi.org/10.2478/aslh-2014-0001

27. SMIT G, RETHMAN N 2000 The influence of tree thinning on the soil water in a semi-arid savanna of southern africa. J Arid Environ 44 (1): 41-59. DOI: https://doi.org/10.1006/ jare.1999.0576

28. EICHHORN J, ROSKAMS P, FERRETTI M, MUES V, SZEPESI A, DURRANT D 2010 Visual assesment of crown condition and Damaging Agents. 49 pp. Manual Part IV. In: Manual on methods and criteria for harmonized sampling, assessment, monitoring and analysis of the effects of air pollution on forest. UNECE ICP Forest Programme Co-ordinating Centre, Hamburg, Germany. URL: http://www.icp-forests.org/ Manual.htm (20 January 2016)

29. MÁTYÁS CS 2010 Forecasts needed for retreating forests. Nature 464 (29): 1271 . DOI: https://doi. org/10.1038/4641271a 
30. SOPP L 1974 Fatömegszámítási táblázatok [Tables for yield volume calculations]. Mezőgazdasági Kiadó, Budapest, Hungary, $361 \mathrm{p}$ (in Hungarian)

31. SZALAI S, AUER I, HIEBL J, MILKOVICH J, RADIM T, STEPANEK $P$, ZAHRADNICEK P, BIHARI Z, LAKATOS M, SZENTIMREY T, et al. 2013 Climate of the Greater Carpathian Region. Final Technical Report. URL: www.carpatclim-eu.org (20 January 2016)

32. THORNTHWAITE CW, MATHER JR 1955 The water budget and its use in irrigation. In Water, The Yearbook of Agriculture. US Department of Agriculture, Washington DC, USA, pp 346-358

33. GRANIER A, BRÉDA N, BIRON P, VILLETTE S 1999 A lumped water balance model to evaluate duration and intensity of drought constraints in forest stands. Ecol Model 116 (2-3): 269-283. DOI: https://doi.org/10.1016/S03043800(98)00205-1
34. REINECKE LH 1933 Perfecting a stand-density index for even-aged forest. J Agric Res 46 (7): 627-638

35. WHITE J 1981 The allometric interpretation of the self thinning rule. J Theoret Biol 89 (3): 475-500. DOI: https:// doi.org/10.1016/0022-5193(81)90363-5

36. IGMÁNDY Z 1987 Die Welkeepidemie von Quercus petraea (Matt.) Liebl. in Ungarn (1978 bis 1986). Österr Forstz 98: 48-50

37. KOTROCZÓ ZS, KRAKOMPERGER ZS, KONCZ G, PAPP M, BOWDEN RD, TÓTH JA 2007 A Síkfőkúti cseres-tölgyes fafaj összetételének és struktúrájának hosszú-távú változása [Long term changes in the composition and structure of an oak forest at Síkfőkút, North Hungary]. Természetvédelmi Közlemények 13: 93-100 (in Hungarian)

38. BRÉDA N, GRANIER A, AUSSENAC G 1995 Effects of thinning on soil and tree water relations, transpiration and growth in an oak forest (Quercus petraea (Matt.) Liebl.). Tree Physiol 15 (5): 295-306. DOI: https://doi.org/10.1093/ treephys/15.5.295 